Article

\title{
Immigration, Identity, and Genealogy: A Case Study
}

\author{
Thomas Daniel Knight \\ Department of History, The University of Texas—Rio Grande Valley, Edinburg, TX 78539-2999, USA; \\ thomas.knight@utrgv.edu
}

Received: 31 August 2018; Accepted: 18 December 2018; Published: 2 January 2019

\begin{abstract}
This paper examines the life and experiences of a 19th-century immigrant from the British Isles to the United States and his family. It examines his reasons for immigrating, as well as his experiences after arrival. In this case, the immigrant chose to create a new identity for himself after immigration. Doing so both severed his ties with his birth family and left his American progeny without a clear sense of identity and heritage. The essay uses a variety of sources, including oral history and folklore, to investigate the immigrant's origins and examine how this uncertainty shaped the family's history in the 19th and 20th centuries. New methodologies centering on DNA analysis have recently offered insights into the family's past. The essay ends by positing a birth identity for the family's immigrant ancestor. Importantly, the family's post-immigration experiences reveal that the immigrant and his descendants made a deliberate effort to retain aspects of their pre-immigration past across both time and distance. These actions underscore a growing body of literature on the limits of post-immigration assimilation by immigrants and their families, and indicate the value of genealogical study for analyzing the immigrant experience.
\end{abstract}

Keywords: immigration; identity; genealogy; name-change

\section{Introduction}

This paper examines the life and experiences of a 19th-century immigrant from the British Isles to the United States. It stems from an inquiry into a family story first told to the author in the early 1980s (Lester 1982). "Catherine Johnson's father", the story goes, "was not born a Johnson. He was born in Wales, and joined the Royal British Navy as a young man. When he got to America, he jumped ship, swam ashore, and changed his name to Johnson so that he would not be caught and prosecuted for desertion" (Lester 1982). From that initial statement, this inquiry began. Could the story be verified? Who was this man? What could be learned about his origins, and how?

Primary source research into county records revealed that his name was William Johnson and that the first known reference to him in America dates from 1822, when he married in Putnam County, Georgia. ${ }^{1}$ As will be explained in more detail later, oral traditions collected from several different branches of the Johnson family support the story originally told to the author, and indicate that Johnson was born in the British Isles, but that he changed his name and created a new identity for himself when he came to America. Connections with his birth family and homeland were severed, although aspects of his birth identity were preserved in the oral traditions passed down among descendants.

This article will provide a short review of the literature concerning genealogy, oral history, folklore, and identity. The case study of William Johnson follows, along with an analysis of the oral history stories preserved among his descendants. An important theme here is how the experience of

1 Johnson, William. Marriage to Mary Worsham. 1822. Putnam Co., GA, Marriage Book X, p. 131, Putnam County Courthouse, Eatonton, GA. 
immigrating severed the American Johnson family's physical link with its European background. Yet, the Johnson family retained clues to its origins, and passed them across successive generations in its family stories. Using elements of the family's oral history traditions, primary source historical research concerning William Johnson, and observations garnered from modern DNA analysis techniques, the article then posits a possible solution to the mysterious origins of William Johnson. The essay ends with a reflection on the tenuous and changing nature of personal identity. It is important to note here that the story of William Johnson runs contrary to some assimilationist theories of the immigrant experience (Gordon 1964; Alba and Nee 2003). By showing that for nearly two centuries the American Johnson family maintained the family tradition of its past in Wales and England and transmitted those stories not only across time but also across multiple branches of the family separated by significant geographical distances, this research supports new interpretations that stress the ways in which immigrants retain elements of their pre-immigration past and identity while they adapt into the receiving society in many other aspects of their lives (Waters 1990; Portes and Zhou 1993; Portes et al. 2005; Lee and Bean 2004). In this sense, the intersection of genealogy, oral history, folklore, and identity studies helps to enrich our understanding of immigration, adaptation, and settlement.

\section{Background and Literature Review: Genealogy, Oral History, Folklore, and Identity}

The analysis of the William Johnson family that follows utilizes methodologies from genealogical studies as well as from oral history, folklore studies, and scholarship on identity formation to identify William Johnson and contextualize his immigration to the United States. Successful genealogical investigations hinge on correctly identifying individuals and placing them in the appropriate historical context. In some well-documented cases, the identifications can be easily made when clear evidence concerning individuals has survived. Examples of evidence of this type include family Bible records identifying family members, letters discussing individuals and their family connections, birth certificates and marriage certificates that clearly tie individuals together, wills and deeds that make family connections explicit, and, sometimes, published narratives from the past that recorded this information while the individuals concerned were still living and could verify it (Jacobus 1999; Szucs and Luebking 2006).

In cases where such information has not survived, documenting connections can be much more challenging. How does one determine whether two individuals with the same name are the same person? What constitutes sufficient evidence to make such an identification? These are questions that genealogists, prosopographers, historical demographers, and social historians work with every day (Jacobus 1999; O'Daniel 2007; Willigan and Lynch 1982; Stone 1971; Keats-Rohan 2007). Correctly identifying an individual and verifying the connections lays the cornerstone for further analysis. Many social historians utilize a prosopographical technique called family reconstitution to place individuals in their correct historical context (Stone 1971; Demos 2004). By gathering a wealth of information concerning an individual and his or her family, that person's social world-a universe in microcosm — can be recreated, and family connections can be determined and verified (Wrigley et al. 1997; Akerman 1977).

This is a laborious process that is made all the more difficult in cases such as that of William Johnson, where identifications have been fragmented by immigration and name change. Sources that might otherwise be useful, such as local migration patterns, are not applicable. Likewise, searching for individuals with the same or a similar name is of limited use when the surname was only adopted after an individual reached his or her destination. In the study that follows, the author has used family reconstitution methods to identify and trace William Johnson after his arrival in the United States (Wrigley et al. 1997).

Information concerning William Johnson prior to his arrival in the United States comes from oral history interviews with his descendants (Lester 1982; Ragsdale 1995; Anderson 1989; Johnson 2003; Johnson 2014). These Johnson descendants—born between 1892-1930-were interviewed over a period of 30 years concerning their family history, including later developments in the 19th and 20th 
centuries, as well as what they knew of their family's early origins. As a research methodology, oral history "can be defined as the recording, preservation, and interpretation of historical information, based on the personal experiences and opinions of the speaker" (East Midlands 2018). It is important to note that the information that is presented in the interviews is subjective, and is presented through the experiences and views of that particular individual; it is also susceptible to the frailties of human memory and the multiple ways in which memory can be constructed by those recalling events. Oral history "may take the form of eyewitness evidence about the past, but can include folklore, myths, songs, and stories passed down over the years by word of mouth" (East Midlands 2018; Dunaway and Baum 1996; Charlton et al. 2006). In the case of William Johnson, questions about the family's background were a precursor to questions about later historical developments. However, for the purposes of this article, the information that was revealed concerning Johnson's origins and arrival in the United States will primarily be considered.

It is important to note that none of William Johnson's descendants who were interviewed knew him personally. Johnson died about 1840, and the oldest of those interviewed was born in 1892. Hence, all of the information concerning Johnson's origins took the form of family stories handed down across generations. Three of those interviewed knew children of William Johnson personally; others interviewed knew grandchildren of William Johnson personally. Hence, the information conveyed was separated from the original subject-William Johnson-by two or three generations of family relationships. It is also noteworthy that in each case, the background knowledge concerning William Johnson was limited, although the accounts did contain many specific details that had been relayed across generations to those who were relating them in the interviews. Despite these limitations, enough specific information survived to make analysis possible (Charlton et al. 2006).

For this reason, the author has treated the Johnson family stories as folklore and utilized insights from folklore studies to analyze them (Bendix and Hasan-Rokem 2013; Dorson 1972). As folklore, the stories may hold other insights into the time and place in which they were created, but the primary purpose for this study has been to decode what the stories reveal about the origins of the immigrant William Johnson in an effort to unravel the mystery of his origins and birth identity. Since the accounts vary in some details, one additional question that was considered was whether the family stories were accurate, or whether the stories themselves might have been fashioned and refashioned through the process of transmission across generations (Charlton et al. 2006).

In terms of the search for William Johnson's birth identity, it is important to clarify the term 'identity' before proceeding. Identity here is used in multiple senses. In its most basic, in Johnson's case, it refers to who he was as a person at the time that he entered the world: his place of birth, his parentage, his family's origins. These are the palpable dimensions of personal identity, although they can be altered through the process of self-fashioning, the process of constructing one's identity and public persona according to a set of socially acceptable standards, and self-invention-i.e., the act of inventing or creating one's identity anew (Greenblatt 1980; Eakin 1985). However, the term 'identity' is also employed to refer to identity formation and the idea that identities-individual, group, or even national—can be socially constructed and are malleable (Shotter and Gergen 1989; Christiansen et al. 1999; Anderson 1983). By changing the circumstances of one's life-education, religion, residence, friends, associates, occupation-individuals can create new identities for themselves. This can happen actively, through specific behaviors and occurrences; it can also happen discursively, through spoken words. Finally, it can happen interactively, through social relationships, as individuals bond with others or perceive a sense of "otherness" and "difference" that sets them apart or of "sameness" that unites them (Harré and Moghaddam 2003; Kalaga and Kubisz 2008). Part of the search for William Johnson's origins is to understand who he was by birth and background. A second part is to understand who he became: how he became William Johnson and what that also meant, if the family stories are correct, and Johnson abandoned his birth identity and created a new identity-both a name and a persona-for himself in a new world. The remainder of this essay is positioned in terms of scholarship on genealogical methodology, oral history, folklore studies, and identity formation to 
determine what William Johnson's birth identity actually was and whether the family legends that were communicated through oral history interviews about him more than a century after his death were correct.

\section{Case Study: William Johnson}

In this instance, the immigrant William Johnson chose to create a new identity for himself after immigration. Doing so both severed ties with his birth family and left his American progeny without a clear sense of identity and heritage. The remainder of this essay uses a variety of sources, including oral history and folklore, to investigate Johnson's origins and examine how this uncertainty about their past shaped the family's history in the 19th and 20th centuries.

Within the Johnson family's oral history, there was no recorded mention of their immigrant ancestor's given name. Subsequent research showed that it was William. However, what family history did preserve was a tradition about the family's history derived from several different accounts of his origins and arrival in the United States. These accounts are summarized below.

Account 1. The family of Seaborn Johnson (1849-1889), William's grandson, maintained that their immigrant ancestor arrived from Wales or Ireland. His birth name was Paiton, Paton, or perhaps Painton. One written document from the 20th century spells the name Peyton. Few other details were preserved other than that the immigrant had stolen a horse prior to coming to America, and may have been fleeing to avoid prosecution (Johnson 2014).

Account 2. Descendants of Travis Calvin Johnson (1872-1955), Seaborn's much younger half-brother, had a similar story. In this case, it may be important that William Wren Johnson, the father of the brothers, died in 1880, and that the two families lived several hundred miles apart from the 1870s onwards. Seaborn's family lived in Leon County, Texas. William Wren Johnson moved further north with his second family, and after his death in 1880, his son Travis Calvin Johnson ultimately settled in Stephens County, Oklahoma, about 300 miles from Leon County. In the 1920s, Travis Calvin's son-another William Wren Johnson-moved to California. Members of Travis's family in California and Oklahoma both reported that that the Johnson immigrant came from Wales or Ireland to the United States and changed his name on arrival. Their story included the horse theft incident and maintained that the original name had been Paiton, Paton, Patton, Paten, or perhaps Pate (Johnson 2014).

Account 3. Descendants of Rhoda Reeves (1866-1907), daughter of Catherine Johnson Reeves (1835-1910), reported a somewhat different story. Unlike her brothers, Catherine never left Georgia, where all seven children of William Johnson were born, and her children also remained there. Although the story does include immigration and a name change, the circumstances differ. In this case, Johnson was a native of Wales. He joined the Royal British Navy in Wales or England and came to America in the naval service. When he arrived in America, he "jumped ship", swam ashore, and fled. At that point, he changed his name to Johnson to avoid prosecution for desertion. The horse-theft element is absent from this version, but a name change is present. There was no mention of Ireland, but Wales was clearly identified as his point of origin; this detail was amplified by the additional element that Catherine, who was his daughter, recalled him speaking in Welsh on the family farm when she was a child. In this version, the original name was Hayes (Lester 1982; Ragsdale 1995).

Account 4. Descendants of Louisa Reeves (1875-1948), Rhoda's sister, had a similar tale. In this version, the immigrant ancestor came from a noble family in England and was born "Lord Peyton". As a young man, he joined the Royal British Navy against his family's wishes and came to America in the naval service. In this version, despite being an heir to a fortune at home, Johnson had looked upon the United States as a land of adventure and opportunity, and planned to escape from the navy and make his own way there. From this point onwards, the story was the same as that passed down in the family of Louisa's sister Rhoda, except that the original name was not Hayes, but instead Paton or Peyton, which was the same name given in the two Johnson versions (accounts 1 and 2) above (Anderson 1989). 
Account 5. Descendants of James Marion Johnson (1867-1953), son of Augustus Johnson (1832-1918), had another version of the tale. James Marion Johnson was born in Louisiana, but lived most of his adult life in Live Oak County, Texas, about 100 miles from the United States-Mexico border. Augustus Johnson had been reared in the same household with his older brother William Wren, but after William married in 1845, Augustus moved to Troup County, Georgia, with his mother and younger siblings, including Catherine (1835-1910). However, by about 1855, William and Augustus had reunited and moved together to Columbia County, Arkansas. They would live as neighbors for about 20 years in Columbia County, Arkansas, and Sabine Parish, Louisiana. Thereafter, the families went in separate directions, with Augustus's family moving into southern Texas and William Wren's family moving into northern Texas, although there is evidence of communication between the two families as late as 1908. There is no evidence of communication between either William Wren or Augustus and their siblings in Georgia after 1855. The chronology is important, because the story that was preserved in the Augustus Johnson family had similarities to the tale told by Catherine Johnson's family in Georgia, but with some additional details. According to this version, the immigrant ancestor came from the "point" where England and Wales come together in the region where England, Wales, Ireland, and Scotland are all close together. Unlike the other versions, there was no tradition of a name change as this version was related. In this version, the Johnson ancestor was visiting an inn when he was kidnapped and forced into the naval service, waking up on a vessel bound for America. After reaching America, he "jumped ship" and swam ashore to escape the men who had forced him into service. This story differed from the others in that it offered a more detailed account of William Johnson's place of origin, and it did not include the tradition of a name change (Johnson 2003).

These examples show that at least five different stories have survived that account for the origins of the Johnson family in America. All five tell of an immigrant ancestor who came to America in the early 19th century. An analysis of these different accounts shows at least six other salient elements that contain clues as to the Johnson family's origins:

(1) William Johnson may have originated in England, Wales, or Ireland, possibly in an area near the border between England and Wales that also has proximity to Scotland and Ireland (Johnson 2003).

(2) Johnson may have had prominent heritage, as indicated by the story that he was born into a noble family (Anderson 1989).

(3) Johnson may have changed his surname to Johnson upon his arrival in the United States (Lester 1982; Johnson 2014; Ragsdale 1995; Anderson 1989).

(4) The surname may have originally been Paiton or something similar (Johnson 2014; Anderson 1989).

(5) Johnson may have served in the Royal British Navy and subsequently deserted (Lester 1982; Ragsdale 1995; Anderson 1989; Johnson 2003).

(6) Johnson may have stolen a horse at some point (Johnson 2014).

Although some elements of the tales seem consistent, others are difficult to reconcile. Particularly puzzling is that one set of stories has the immigrant William Johnson as a horse thief, while another set of stories has him as a naval deserter.

In terms of Johnson's decision to come to or remain in America, at least one story reveals that he planned his immigration in advance (Anderson 1989), while at least two have his decision as a result of contingency (Ragsdale 1995; Johnson 2003). In the latter scenario, naval service brought Johnson to America, and the opportunity for escape proved the motivating factor. However, all five stories do have a common theme: escape. In two, Johnson was escaping prosecution for horse theft, which is a criminal act that could have resulted in execution (Johnson 2014; Fuchs 2005; Luckett 2014). In two, he was escaping naval service, which may have been forced upon him (Ragsdale 1995; Johnson 2003). It is of significance that this possibility is consistent with historical evidence. The British Navy in the early 19th century was particularly harsh, and impressment into naval service had been an important cause of the War of 1812 (Hubley 2009; Magra 2016). In the third version of this story, naval service was voluntary, and Johnson's decision to immigrate was premeditated, but a desire to escape his past 
and recreate himself in America proved the overall motivating factor. Significantly, in this version, Johnson had come from a privileged background, and his decision was made not for, but rather against, the financial security that was guaranteed to him at home (Anderson 1989).

Treating the stories as folklore, it is possible to see that the stories themselves have a genealogy. By examining the chronology of the accounts and the physical locations from which they emerged, one may analyze their development and transmission. By labeling the horse-theft story as "Version A" and the naval deserter story as "Version B", the following patterns emerge:

- Version A. Version A seems to follow the lineage of William Wren Johnson, who was born in 1825. Since the story was transmitted by two different branches of William Wren's family, which each descended from a different one of his marriages and were separated by a significant distance, it would appear that Version A may trace back to William Wren Johnson himself. Johnson's older son Seaborn was already married with a family of his own by the time that his younger son Travis Calvin was born, and Johnson had already moved with his second family to a different geographical area by this time, lessening the likelihood that the story could have been transmitted later to Travis Calvin's family by members of Seaborn's family (Johnson 2014).

- Version B. Version B seems to follow the lineage of Augustus Johnson, who was born in 1832, and Catherine Johnson, who was born in 1835. The two families separated in the 1850s, and are not known to have communicated afterwards. When they died in 1910 and 1918, Catherine and Augustus were living almost 1000 miles apart. The story of naval desertion would also seem to date to the lives of these two siblings and have been passed down by them (Lester 1982; Anderson 1989; Ragsdale 1995; Johnson 2003).

Both variants of Version A have the tradition of a name change, as do two variants of Version B. Both variants of Version A and one variant of Version B hold that the original name was originally Paiton, Paton, or something similar (Anderson 1989; Johnson 2014).

It is difficult to reconcile the two traditions about how and why the family's Johnson ancestor came to America; it may be that an element of both is correct, and that the horse theft preceded the naval desertion or vice versa. It may also be that certain details have been emphasized in one version as opposed to another due to the context in which those stories were developed, transmitted, and retold. That is, it may be that the memories and experiences of those telling and retelling the stories have shaped what details were emphasized, and how they were presented. For instance, the story of aristocratic origins survived in Georgia, which is a society with an antebellum culture that privileged lineage and gentility, while the horse-theft story survived among the descendants who settled in Texas, Oklahoma, and points westward.

However, insights from folklore studies can help make sense of conflicting aspects of the William Johnson stories. Folk tales can be used to preserve the past, teach moral lessons, warn against certain behaviors, and reinforce behaviors that society values. Folklore comes in many forms, including myths, legends, folk tales, tall tales, fables, dances, plays, superstitions, and traditional art forms. Some forms, such as tall tales and folk tales, may exist purely for entertainment, but can still teach lessons. Others, such as fables, rely on personalization to teach moral lessons. Legends are usually about real people, but may contain information that has been exaggerated. Examples might include well-known stories about real historical figures such as Daniel Boone or George Washington that lack firm historical evidence (Dorson 1972; Bendix and Hasan-Rokem 2013).

Folklore scholars have noted the tendency for certain elements to be privileged in storytelling. Sometimes, this leads to multiple, quite different versions of the same tale. However, folklore scholars suggest that even very different stories may contain hidden truths. As Karri Toomeos-Orglaan wrote, storytelling "is a way of interpreting the world; through narrations of past events, a storyteller can mediate to the listeners his or her vision or interpretation of these events". In this sense, "the narrative tradition [can be seen] as a long chain, which extends from today far into the past. Each narrator forms one ring in the chain." As time passes, storytellers "use the material from previous narrators 
and complement the existing stories with new elements, [and in] this way providing a new context to the story". In this way, Toomeos-Orglaan noted, "storytelling involves both collectiveness and individuality, both past and present ... each independent story is a possible version by itself, and only all of them together form tradition" (Carrassi 2012; Toomeos-Orglaan 2013).

Thus, the multiple versions of the William Johnson legend can be seen to represent a "tradition" constructed by the Johnson family to explain how and why it came to be in the United States. While there are conflicting elements, both versions indicate the continued interest of family members in their own unknown heritage, and suggest a need to preserve some sense of identity by transmitting this information across generations, ultimately from the 19th to the 21st century. The stories also underscore the cleavage that the act of immigration itself could have in terms of separating an individual from her or his roots. If the stories preserved among the Johnson descendants about the circumstances of William Johnson's immigration are historically accurate, the only person who would have known Johnson's birth identity would have been the immigrant himself. Everyone who met him in America would have known only the identity that he chose to create and the information that he chose to convey to those he came to know closest, who were probably his wife and children. Moreover, his early death in about 1840 meant that the source of that information-Johnson himself-was no longer available, and that the transmission of information in the future would be limited to those who were one or two degrees removed from the original source. This helps explain how conflicting accounts could stem from a common root, with different tellers privileging certain elements as they transmitted them. The act of retelling, and the purposes of retelling, may have subtly altered aspects of the tale. Still, the stories are detailed enough that they hold the possibility of unlocking the mystery of the family's origins if the details preserved should prove accurate.

\section{Origins and Identity}

Until recently, documented information concerning the immigrant William Johnson was scarce. Primary source research in Georgia county records shows that he married Mary Worsham in Putnam County, Georgia, in $1822^{2}$; that they almost immediately began a family together; that they had seven children between 1822-1837; and that William Johnson died about 1840. From these data, a more complete portrait of Johnson begins to emerge as a husband, father, and individual. The historical evidence shows that he moved frequently, living in at least six counties in Georgia and Alabama between his marriage and death. He seems never to have owned property, and to have worked as an agricultural laborer and tenant farmer. Although not destitute, he never amassed a significant amount of wealth, and after his death, his family supported themselves through a mixture of subsistence farming, factory work, and agricultural labor for others. ${ }^{3}$

In addition, using family reconstitution methods to document William Johnson's offspring revealed new sources of information about his background, since data recorded by William's children in census records adds to the oral tradition concerning his place of origins. The following chart summarizes the documentary evidence in which the children of William Johnson reported their father's birthplace. Beginning in 1880, the US federal census asked those enumerated where their parents were born. The 1880, 1900, and 1910 censuses all asked this question. Augustus Johnson, who lived until 1918 and was the last of the Johnson siblings to die, was the only one of them to have a recorded death certificate; this certificate also asked for the names of an individual's parents and their places of birth. No information was given for Augustus's mother, but his father's name was listed as William Johnson, and his father's place of birth was given as Wales. ${ }^{4}$ See Table 1.

2 Johnson, William. Marriage to Mary Worsham. 1822. Putnam Co., GA, Marriage Book X, p. 131, Putnam County Courthouse, Eatonton, GA.

Johnson, Mary, census entry. 1850. Troup County, GA, Census, p. 126.

4 Data in the chart are drawn from the following sources:Johnson, S., census entry. 1880. Tallapoosa County, AL, Census, p. 60B.Johnson, W., census entry. 1880. Taylor County, TX, Census, p. 2B.Buchanan, Julia, census entry. 1880. Fulton County, 
Table 1. Data about their father's place of birth given in census records.

\begin{tabular}{ccccc}
\hline & 1880 Census & 1900 Census & 1910 Census & Death Certificate \\
\hline Seaborn Johnson & “Whales" & N/A & N/A & N/A \\
\hline William Wren Johnson & England & N/A & N/A & N/A \\
\hline Julia Johnson Buchanan & Georgia & N/A & N/A & N/A \\
\hline Bathsheba Johnson Adams & Wales & Georgia & Georgia & N/A \\
\hline Augustus Johnson & Ireland & England & Unknown & Wales \\
\hline Catherine Johnson Reeves & Wales & Wales & Wales & N/A \\
\hline Mary Jane Johnson Mackey & Wales & Wales & N/A & N/A \\
\hline
\end{tabular}

Note: In one instance, a death certificate, for the children of William Johnson between 1880 and 1918.

The information concerning William Johnson's origins is conflicting, but of the 14 instances where the census recorded a specific place, nine (64.3\%) indicated Wales, two indicated England (14.2\%), one indicated Ireland (7.1\%), one indicated unknown (7.1\%), and one indicated Georgia (7.1\%). The death certificate of one son also indicated Wales as the immigrant's birthplace. As previously noted, family oral history accounts vary, but also list Wales, England, and Ireland as places of origin. Descendants of one son alleged that Johnson came from the "point" where England, Wales, Ireland, and Scotland are all close together (Johnson 2003). Cumulatively, this evidences a strong tendency across both time and place to preserve a sense of the family's pre-immigration past among its descendants.

American records and oral traditions passed down in the Johnson family provide clues as to Johnson's background and origins. Still, nothing provides specific information about the name William Johnson had before he came to America or where he was born. However, beginning in 2013, descendants of William Johnson began to avail themselves of modern DNA analysis technology in multiple forms, including Y-DNA analysis, X-DNA analysis, autosomal DNA analysis, and mitochondrial DNA analysis. Y-DNA provides markers that trace descent in the paternal line. X-DNA, similar to Y-DNA, is a gender determinant that is also passed through only certain lines of descent. Autosomal DNA focuses on matching segments along the 22 pairs of chromosomes. Mitochondrial DNA helps identify the direct maternal line; in William Johnson's case, mitochondrial DNA would not help identify his origins, since he did not pass his mother's mitochondrial DNA on to his offspring.

Between 2013-2018, many of William Johnson's descendants took one or more of these DNA tests from commercial testing companies promoting family history and genealogy. ${ }^{8}$ The cumulative results show a close genetic connection between the American descendants of William Johnson and descendants of George Johnston (1766-1828) and his wives Ann (-) Johnston (c. 1770-c. 1795) and Ann (Berkeley) Paitson Johnston (1763-1826), who lived in Liverpool, England, and Denbighshire, Wales, in the late 18th century. Comparing the known history of the family of George Johnston with the oral history of the William Johnson family reveals interesting parallels.

GA, Census, p. 18B.Adams, Bathsheba, census entry. 1880. Meriwether County, GA, Census, 16D.Adams, Basha, census entry. 1900. Pike County, GA, Census, p. 174A.Adams, Bashey, census entry. 1910 Pulaski Co., GA, Census, p. 102B.Johnson, Andy, census entry. 1880 San Saba Co., TX, Census, p. 393C.Johnson, Agustus, census entry. 1900 Live Oak Co., TX, Census, p. 114A.Johnson, Agustus, census entry. 1910 Live Oak Co., TX, Census, p. 282A.Johnson, Augustus, death certificate. 1918. Live Oak Co., TX.Reeves, Katie, census entry. 1880 Fulton Co., GA, Census, p. 44D.Reeves, Katie, census entry. 1900 Polk Co., GA, Census, p. 208B.Reeves, Kattie, census entry. 1910 Polk Co., GA, Census, p. 47B.Mackey, Mary, census entry. 1880 Cobb Co., GA, Census, p. 52D.Mackey, Mary Jane, census entry. 1900 Cobb Co., GA, Census, p. 11B.

5 N/A here represents the expression "Not Applicable," which is used to denote that no record for the individual in question exists, which is usually because they had died prior to the census date. Only one of William Johnson's children lived into the era when American states began requiring the registration of death certificates.

6 Interestingly, Julia's son Bennett Buchanan reported in 1920 that Julia was born in Ireland. While this is incorrect, it may reflect the tradition of foreign origins.

"Unknown" was recorded on the census document.

8 Results are accessible through 23 and Me, Ancestry, and FamilyTree DNA, as well as Gedmatch. 
Previously, this article identified six features emerging from an analysis of the five variants of the family traditions recorded among Johnson descendants. Each will be repeated below with additional analysis based on research into the family of George Johnston.

1. William Johnson may have originated in England, Wales, or Ireland, possibly in an area near the border between England and Wales that also has proximity to Scotland and Ireland. George Johnston (1766-1828) was from a family of Scottish mariners who had lived in Liverpool, England, during the 1760s. His father, another George Johnston, had married Ann Hanley, whose father was a merchant based in Dublin, Ireland, and Liverpool, England. The younger George had grown up in Liverpool and in about 1790 was married there to a woman called Ann. This Ann died in about 1795, and George Johnston remarried to a young widow, Ann (Berkeley) Paitson. Ann had been born in 1763 in Liverpool, but her parents had married in the parish of Gresford, Denbighshire, Wales, in 1759. The village of Gresford is located in northeastern Denbighshire, about two miles from the English border, just south of the point where the Welsh border juts northward into Cheshire, England. After George Johnston married Ann (Berkeley) Paitson in 1796, they returned to Wales, where they lived out the remainder of their lives. They lived until their deaths in the Wrexham area, in villages that included Summerhill and Gwersyllt. They were buried at All Saint's Church, Gresford. Corresponding with the Johnson oral tradition, Wrexham is located near the border between England and Wales, and the swathe of land between the Welsh border and Liverpool north of the city of Chester points outward into the Irish Sea. Liverpool itself is directly south of Dumfries in Scotland, directly east of Dublin in Ireland, and an almost equivalent distance from each. ${ }^{9}$

2. William Johnson may have had prominent heritage, as indicated by the story that he was born into a noble family. Such stories are not uncommon, and usually are of no significance in family history and genealogy research. However, interestingly, there is a longstanding oral tradition in the family of George Johnston that claims he descended from William Johnstone (1663-1721), the second Earl of Annandale and Hartfell, the first Marquess of Annandale, about 10 miles northeast of Dumfries in Scotland. In this story, the Johnston ancestor fell in love with and married a Welsh lady and forsook his inheritance to live with her in Wales. ${ }^{10}$ Whether a prominent heritage existed is immaterial; what may be significant is that descendants of both William Johnson and George Johnston had a similar family story that may have sprung from a common transatlantic root.

3. William Johnson may have changed his surname to Johnson upon his arrival in the United States. The story of a name change is present in four of the five recorded oral history tales among the William Johnson descendants, and the fifth does not maintain that there was no name change: it just includes no overt reference to a surname change. George Johnston (b. 1766) and his first wife had a son, William Johnston, who was born in 1788 in Liverpool. George Johnston's second wife Ann (Berkeley) Paitson had married Richard Paitson in Liverpool in 1785; their son William Paitson was born at Gresford in Wales in 1786, but spent most of his childhood in Liverpool, where his mother remarried George Johnston when he was 10. The immigrant William Johnson could have been either William Johnston or William Paitson. Either possibility would involve a name change, although that from Johnston to Johnson would have been less obvious than that from Paitson to Johnson. ${ }^{11}$

9 The following sources document this family: Gresford Parish Registers, 1661-1976, accessible at Findmypast.co.uk; Cheshire Marriage License Bonds and Allegations, 1606-1905, accessible at Findmypast.co.uk; England and Wales Non-Conformist Births and Baptists, accessible at Findmypast.co.uk; England Marriages, 1538-1973, accessible at Findmypast.co.uk.

10 "William Johnston and Ann Harris", accessible at FamilySearch (https://www.familysearch.org/tree/person/memories/ L2QG-W96), accessed 15 May 2018.

11 Gresford Parish Registers, 1661-1976, accessible at Findmypast; William Johnston, born 1788, Liverpool, accessible at FamilySearch.org. 
4. The surname may have originally been Paiton or something similar. George Johnston's second wife was Ann (Berkeley) Paitson, widow of Richard Paitson, by whom she had a son William Paitson, who was born in 1786. Paitson lived in Liverpool before returning to Wales with his mother and stepfather, George Johnston. He was living in the parish of Gresford in 1808 when he fathered an illegitimate son. Welsh parish registers and the English and Welsh censuses contain no reference to William Paitson after 1808, indicating that he either died or left the area after that date. ${ }^{12}$ The name Paitson is strikingly similar to the name Paiton, which appears in three versions of the William Johnson family tradition. Prior to settling in Liverpool, the Paitson family had originated in Cumberland, in Northern England, where the regional north-country accent may also have altered its pronunciation slightly.

5. William Johnson may have served in the Royal British Navy and subsequently deserted. No evidence has been found so far to confirm or disprove the story of British naval service and desertion. Still, the story seems plausible on several accounts. The Johnstons of Liverpool and their Hanley and Gregson relatives were part of a network of Liverpool merchants and mariners engaged in the transatlantic trade. At least one son of George Johnston did serve in the British navy. Born in the late 1780s, both William Johnston and William Paitson would have come of age about 1810, during the era of the Napoleonic Wars. War between the United States and England erupted in 1812 and lasted until 1815, and the Royal Navy played a key role in the conflict. Maritime service during this period would have been a likely possibility for men of that generation. As the family tradition suggests, it would also explain Johnson's arrival in America. Desertion during the War of 1812 or soon after it ended would place Johnson in the United States in time to have married Mary Worsham in 1822 (Hubley 2009; Magra 2016).

6. Johnson may have stolen a horse at some point. No evidence has been found so far to confirm or disprove the story of horse theft, but it remains a possibility.

Cumulatively, several aspects of the Johnson family oral traditions correspond with the known facts concerning the family of George Johnston (1766-1828) of Liverpool, England, and Denbighshire, Wales. The geography is perfectly consistent with the oral traditions. The story of noble origins is present in both families. The surname Paitson is strikingly similar to Paiton or Paton as indicated in the family tale. The Johnstons and Paitsons were part of Liverpool's maritime community, and the possibility of naval service in the period between 1810-1820 is very likely given both the chronology - the era of the Napoleonic Wars and the War of 1812—and geography.

Adding to the oral history and supporting historical documentation, the autosomal DNA linkages suggest that William Johnson was very likely either William Johnston, born 1788 in Liverpool, England, son of George Johnston and Ann (-) Johnston, or his stepbrother William Paitson, born in 1786 in Gresford, Denbighshire, Wales, son of Richard Paitson and Ann (Berkeley) Johnston Paitson. Both men spent part of their childhood in Liverpool before moving to Wales. No clear record of either man has been found after he reached adulthood, suggesting that both either died young or permanently left the area. However, additional DNA connections to the Paitson family of Cumberland, England, where Ann (Berkeley) Johnston's first husband Richard Paitson originated, provide clear evidence of a linkage between the American Johnsons and the British Paitsons, and suggest very strongly, along with the DNA connections to the Berkeley-Johnston family, that the immigrant William Johnson was the same man as William Paitson, who was baptized in the parish of Gresford, Denbighshire, Wales, in 1786 .

Hence, it becomes possible to reconstruct a plausible scenario that explains William Johnson's origins and birth identity. The parents of Ann Berkeley had originated in northwestern Denbighshire, Wales, within a couple of miles of the border with England. William Berkeley married Eleanor Dowell

12 Gresford Parish Registers, 1661-1976, accessible at Findmypast. 
in the parish of Hope in neighboring Flintshire, Wales, on 25 May 1762. Berkeley had come from the adjoining parish of Gresford, while Dowell lived within the parish of Hope; his ancestors had lived in Gresford, Minera, and nearby Wrexham for more than a century. ${ }^{13}$ Soon after marriage, the couple moved to Liverpool, England, about 40 miles to the northwest. Although Gresford was a rural parish, it was four miles north of Wrexham, which was the largest commercial and manufacturing center in North Wales (Davies 2007). Liverpool in the 18th century witnessed tremendous growth as reflected in its population, which increased from about 5000 in 1700 to more than 77,000 by 1800 . The key to much of this growth was England's commercial expansion; Liverpool's location, where the River Mersey enters the Irish Sea, provided a strategic outlet for trade with northwestern England. From Liverpool, boats could travel to Ireland, Scotland, America, and beyond. However, one nefarious aspect of the city's growth was its connection to the transatlantic slave trade, and Liverpool became a major slave-trading port that would dominate the transatlantic slave trade in the second half of the $18^{\text {th }}$ century. The city's bustling economy drew migrants from throughout northwestern England, Scotland, Wales, and Ireland (O'Connor 1994).

The family's history for the next half-century would center around Wrexham and Gresford in Wales and Liverpool in England. Soon after reaching Liverpool, in March 1763, the Berkeleys gave birth to a daughter, Ann. In Liverpool, William Berkeley worked as a laborer-probably a dockside worker in the maritime sector-but parish records suggest that the Berkeleys moved back and forth between Liverpool and Wales. For instance, William Berkeley would die in Liverpool in 1782, but his widow Eleanor would die in Wrexham the following year. Ann Berkeley, the eldest of the Berkeley children, married Richard Paitson in Liverpool in 1785. Paitson's family had migrated to Liverpool from near Whitehaven in Cumberland, about 100 miles to the north, in the middle of the 18th century to work in the sea trade. Paitson himself was a painter; whether he practiced his trade in connection with overseas commerce, perhaps on ships or the dockside, or whether he used his skills in connection with the physical expansion of Liverpool is unknown. Within a year of their marriage, the Paitsons were in Wales, where son William was baptized at Wrexham in 1786. They then returned to Liverpool, where Paitson continued to work as a painter. Sometime in the early 1790s, Richard Paitson died, and Ann Berkeley Paitson then remarried to George Johnston, who was himself a widower with young children, at St. Nicholas, Liverpool, in November $1786 .{ }^{14}$

George Johnston's family was Scottish, and his father, a mariner, may have been the first Johnston to settle in Liverpool. On his mother's side, he had deep roots in the city; his great-grandfather had worked as a dockside porter at the start of the 18th century. ${ }^{15}$ Reflecting the city's growth, the dockside porter's son had become one of the city's wealthiest merchants and bankers, and was the sitting Lord Mayor of Liverpool at the time of Ann Berkeley's birth there in 1763. When Ann Berkeley Paitson married George Johnston, Johnston was living on Dale Street, which was a "hospitable and upmarket area," and working as a bookkeeper (Raynor 2011). The Johnstons lived in Liverpool until about 1796, when they returned to Wales. George Johnston continued to work as a bookkeeper in Wrexham, and in his later years, he was also a schoolmaster. Ann died at Ruabon, near Wrexham, in 1827, and George died there in 1828; they were buried at Gresford Parish Church, in the village where Ann and Richard Paitson had been living when they baptized their son William in $1786 .{ }^{16}$

13 The following sources document this family: Gresford Parish Registers, Minera Parish Registers, and Wrexham Parish Registers, accessible at Findmypast.co.uk.

14 The following sources document this family: Gresford Parish Registers, Minera Parish Registers, and Wrexham Parish Registers, accessible at Findmypast.co.uk. See also: England Deaths and Burials, 1538-1991; England Marriages, 1538-1973; and England Births and Christenings, 1538-1975, at Familysearch.org

15 Liverpool Parish Registers, at Findmypast.co.uk.

16 Gresford Parish Registers, Wrexham Parish Registers, and Ruabon Parish Registers, at Findmypast.co.uk. 
George Johnston's occupation as a bookkeeper, and later as a schoolmaster, and his family's affluent Liverpool connections suggest that the family lived in comfortable circumstances. ${ }^{17}$ This was reflected in a portrait of Johnston that survived into the 20th century, showing him handsomely clad in a rich red jacket and gloves. George's stepson William Paitson, although born in Wales, would have spent the first decade of his life in Liverpool and the second one in and around Wrexham, which, as a result of growing industry, was undergoing a dramatic transformation from a regional market center into the largest town in North Wales. Thus, young Paitson's life was spent in urban settings with complex and vibrant local economies; the occupations of his close relatives-sailor, painter, porter, bookkeeper, school teacher, and, by virtue of George Johnston's marriage to Ann Berkeley, banker, lawyer, merchant, ship-owner-place the Johnstons and Paitsons in the midst of considerable local activity that connected not only Wrexham and Liverpool to one another, but also tied them to both the busy London metropolis and the vast Atlantic world that flowed outwards from Liverpool (Richardson et al. 2007).

Records show that William Paitson ran into problems in about 1808. The Gresford parish register identifies him as the father of an illegitimate son named Edward Williams, who was born 1 May 1808. Paitson and the child's mother, Elizabeth Williams, never married, but public identification as the child's father would have entailed financial and legal responsibility for his care, whether or not Paitson was the child's actual father. Other charges, including fornication, might have followed, to say nothing of the possible difficulties Paitson may have faced within his community, including trouble with Elizabeth's numerous Williams relatives in the area. ${ }^{18}$

It may be that being labeled as Edward Williams' father was the event that triggered Paitson's departure from the area. The Napoleonic Wars had begun in 1803, and from then until 1815, there was almost constant conflict between England and France. A second conflict between England and its former American colonies grew out of the first, and the War of 1812 would last until January 1815 and divide England's military efforts between opposite sides of the globe. The War of the Fifth Coalition was fought in 1809 between Great Britain and the Austrian empire and Napoleon's French empire, and the War of the Sixth Coalition would begin in March 1813. While events escalated in Europe, conflicts with the new United States were intensifying. Americans had long been complaining of American sailors being forcibly impressed into the British Navy, and in June 1807, a dramatic confrontation took place near Norfolk, Virginia, between the HMS Leopard and the USS Chesapeake that brought the two countries to the brink of war. This backdrop of events makes the story of William Johnson's service in the Royal British Navy, whether forced or voluntary, both possible and plausible (Esdaile 2008).

It was William Paitson who left Wales in or after 1808; it was William Johnson who arrived in America. Johnson, one of the most common surnames in the United States, would have been a good choice for someone wanting to conceal his identity, but the decision to adopt a surname similar to that of his stepfather-Johnson instead of Johnston - may have been a clever way of secretly preserving a tie to his British family. Such would have been in keeping with an individual who seems to have been a wily character, for the images of Johnson preserved in the family tales-escaping from prosecution for horse theft, evading British Naval officers, successfully concealing his birth identity to avoid apprehension-resemble the trickster archetype of some mythological and oral traditions (Hyde 2010).

Family stories indicate that after Johnson deserted the British Navy, he feared punishment and a forcible return to the Navy (Lester 1982; Ragsdale 1995; Anderson 1989). As a result, he left the older settled coastal region and headed into the interior, which was a region that until recently had been populated by Creek Indians and was being settled by would-be cotton planters in the 1820s

17 The portrait existed in 1898, when it was viewed by Samuel Thomas Clarke (1874-1899), son of Amos Clarke and Ann Johnston Clarke. Clarke, a member of The Church of Jesus Christ of Latter-Day Saints, was a sent as on a mission trip to Wales from Utah between 1896 and 1898. See: Welsh Mormon History (http:/ /welshmormon.byu.edu/Resource_Info.aspx? $\mathrm{id}=3389$, accessed on 10 October 2018).

18 Gresford Parish Registers, Findmypast.co.uk. 
and 1830s (Kukla 2003; Garrison 2004; Gigantino 2006). As a new immigrant, Johnson might have opted to remain in a familiar environment, perhaps a large town such as Charleston, Savannah, or Augusta, where he might rely on past skills and knowledge to survive in a new environment. Instead, he chose to begin a new life in a new home. Johnson never again lived in an urban setting, and he did not practice any of the trades to which William Paitson would have been exposed in Wrexham and Liverpool. Instead, he became an agricultural laborer, first working for others and eventually, although he never owned land himself, renting the farm where he reared his family. He moved frequently, from Georgia's Putnam County to Upson County to Pike County to Muscogee County to Harris County, and finally into eastern Alabama. The Chambers and Randolph counties in eastern Alabama were formed in December 1832 from lands that were in the process of being vacated by the Creek Indians, and for several years, Creeks remained among the American farmers settling there. This seems to have been William Johnson's final destination-a hinterland frontier in the process of becoming a settled society-and he died there about 1840 . Johnson's post-immigration activities reflect the determination of a single immigrant to create a new life for himself, despite the initial lack of family or community support that might have helped him adapt to a new environment; as will be seen later, this adventurous mode of incorporating into the receiving society continued among his descendants for several generations.

In America, William Paitson exchanged a British identity for an American one. He traded one surname for another. He exchanged an old world for a new one: Liverpool had been founded in 1207, and Wrexham existed as early as 1161. The two Alabama counties in which Johnson lived the last few years of his life had not been created until 1832. Paitson exchanged a complex and sophisticated urban world for a simple and unrefined rural one. It was also visibly different in terms of race and demography. In the England and Wales of his youth, Paitson would have moved among others similar to himself: those with deep roots in northwestern England, southern Scotland, and North Wales. The cotton South in which William Johnson died was a mixture of Americans of many different European origins, enslaved African-Americans, and an ever-shrinking number of Native Americans, who at the time were being relocated westward. Financially, Paitson had grown up in reasonably comfortable circumstances, for in Wrexham, his stepfather worked as bookkeeper for the growing local industries. In America, William Johnson owned no land, worked as an agricultural laborer for wages, moved often, rented the little property he had, and left no estate to bequeath to his offspring. This made for a mobile and rootless existence, which was characteristic of the frontier environment in which his life ended.

In the next generation, one of William Johnson's sons lived on an Alabama farm not all that far from where William Johnson had settled in the 1830s. Two other sons became farmers also, but they shared their father's wanderlust. William and Augustus Johnson moved first from western Georgia to southern Arkansas, and then to the fertile Sabine River Valley of western Louisiana. There their paths would part, with William moving into the north Texas plains and Augustus moving into South Texas, a world of heat, cactus, mesquite, and chaparral. William's family would become farmers in Oklahoma; Augustus's family would become cattle ranchers in Texas, eventually owning thousands of acres and hundreds of head of cattle in Live Oak County (Johnson 2003; Johnson 2014). All four of William Johnson's daughters remained in Georgia. All four married and lived through the American Civil War there. Bashey Johnson and her husband Jesse Adams rented small farms and moved frequently. Julia, Catherine, Mary Jane, and their families tried their hand at farming, but all three eventually settled in Atlanta-the fastest-growing town in Georgia and eventually the home for an enterprising New South economy - where they became factory workers, toiling for wages in the large cotton mills that were springing up through the city in the second half of the $19^{\text {th }}$ century (Lester 1982; Ragsdale 1995; Anderson 1989; Williams 2007). The varied experience of William Johnson's children suggests that although his children were born in America, they, too, may have experienced some difficulty finding their place in American society. The $20^{\text {th }}$-century descendants of the seven Johnson children continued to farm, ranch, and do mill work-although by the 1920s and 1930s, some began to attend college and 
move into other professions, which was an adaptive trend that continued as the century progressed (Lester 1982; Ragsdale 1995; Anderson 1989; Johnson 2003; Johnson 2014).

Still, scattered among these descendants, and repeated at family gatherings for those interested to hear, was the story of William Johnson and his remote origins on the other side of the Atlantic Ocean. "We were not always Johnsons," the stories seemed to say; "once we were something else, something more, something different." Daughter Catherine's family, especially, used the tradition of William Johnson's noble origins to cope with the privations of life as factory workers and tenant farmers in the late 19th century, and everywhere that the stories were told, they conveyed a sense of otherness-adventure, daring, bravado, cunning - that distinguished them from those around them. However, in every case, there were nagging questions. Are the stories true? Who are we really? Will we ever know? While not every aspect of the stories can be verified, the conjunction of DNA analysis with research into the ecclesiastical and legal records of North Wales and Liverpool, England, suggests that the stories did in fact contain a core of truth. William Johnson was originally William Paitson. He was born in Wales and grew up partly there and partly in Liverpool, England. When he was in his early twenties, he left his homeland, traveled across the Atlantic Ocean, and created a new name and a new identity in a land far away. This American Johnson family is his legacy.

\section{Conclusions}

This article reviewed the literature on genealogical methodology, oral history, folklore studies, and identity formation before focusing on the case study of William Johnson, who was an immigrant to the United States around the time of the War of 1812. Johnson was said to have changed his name and severed all connection with his family and country of origin. This produced a mystery about the family's background that puzzled William Johnson's descendants for generations. Combining an analysis of oral history and folklore with primary source-based historical research and modern techniques available as a result of DNA analysis has now uncovered William Johnson's origins and background.

Importantly, William Johnson's post-immigration transformation was not as complete as it might have been. While Johnson did change his name and create a new life for himself, the surname that he took was one of personal significance, since he assumed a variant of his stepfather's surname that was used by his half-siblings and their families in Wales. This suggests an attempt to preserve his heritage at the same time as he reshaped it to ensure his survival in a changed setting. Johnson might have chosen to mask his background and never tell his American family of it. Instead, his children knew important details about his past that could only have come from him and preserved those on census enumerations, in vital records, and, critically, through family stories. For nearly two centuries, the American Johnsons transmitted these stories that preserved the tradition of their origins in Wales and England, and distinguished them from their American present.

However, outside its significance for the Johnson family, William Johnson's story is important because of what it reveals about how immigrants cope with changed circumstances in new settings. British historian Linda Colley has argued that identities are not like hats that can be taken off and put back on but, rather, several can be worn at once (Colley 1992). This case supports Colley's argument by demonstrating how difficult it can be to create and maintain an entirely new identity. William Johnson's decision to remain in the United States severed the physical bond with his birth family and his homeland; in America, he created a new identity for himself and his family. Still, he passed along vestiges of his birth identity to his descendants. Although those elements were obscured through the imperfect lens of historical memory as they were transmitted across generations, they nevertheless demonstrate an ongoing effort on the part of the American Johnsons to retain something of their pre-immigration heritage. Despite the changes that he made, Johnson's new American identity was never completely separate from his pre-immigration British one.

Johnson, then, while he did adapt to life in the United States, seems not to have fully incorporated into the new society. Studying the life experiences of his children, including their migration patterns, 
occupations, and economic activities, suggests that they may not have, either. It was not until the 20th century-100 years after his immigration — that Johnson's descendants began to become geographically and culturally rooted within the receiving society. As that happened, stories about the family's past began to fade away. However, significantly, even today, the story of William Johnson's origins is told among his descendants.

Johnson's case, while singular, may not be unique. For millions of other immigrants, the decision to immigrate - whether forced on them or voluntary—has meant a physical and permanent separation from their background and heritage, often with a change of name and a change of language and culture. Many outwardly adapt to their new environments, but Johnson's example suggests that this tendency toward assimilation is not without limitations. For more than six generations, the American Johnson family maintained traditions about their family's heritage in England and Wales, carrying them from the Atlantic coast-where William Johnson first arrived-all the way to the Pacific. This commitment to maintaining elements of their pre-immigration history suggests that despite the societal push toward assimilation, immigrants may still preserve and celebrate aspects of their heritage that distinguish them from their adopted homelands. Johnson's story illustrates the role that genealogy, oral history, folklore, and identity studies can have in enriching our understanding of immigration, adaptation, and settlement.

Funding: This research received no external funding.

Conflicts of Interest: The author declares no conflicts of interest.

\section{References}

Akerman, Sune. 1977. An Evaluation of the Family Reconstitution Technique. Scandinavian Economic History Review 25: 160-70. [CrossRef]

Alba, Richard, and Victor Nee. 2003. Remaking the American Mainstream: Assimilation and Contemporary Immigration. Cambridge: Harvard University Press.

Anderson, Benedict. 1983. Imagined Communities: Reflections on the Origin and Spread of Nationalism. London and New York: Verso.

Anderson, Kankakee. 1989. Personal Interview, Rockmart, GA, USA.

Bendix, Regina, and Galit Hasan-Rokem, eds. 2013. A Companion to Folklore. Malden: Wiley-Blackwell.

Carrassi, Vito. 2012. The Irish Fairy Tale. A Narrative Tradition from the Middle Ages to Yeats and Stephens. Translated by Kevin Wren. Plymouth: John Cabot University Press.

Charlton, Thomas L., Lois E. Myers, and Rebecca Sharpless, eds. 2006. Handbook of Oral History. Lanham: AltaMira Press.

Christiansen, Thomas, Knud Eric Jorgensen, and Antje Wiener. 1999. The Social Construction of Europe. Journal of European Public Policy 6: 528-44. [CrossRef]

Colley, Linda. 1992. Britons: Forging the Nation, 1707-1832. New Haven: Yale University Press.

Davies, John. 2007. A History of Wales: Revised and Updated Edition. London: Penguin.

Demos, John. 2004. Entertaining Satan: Witchcraft and Culture in Early New England, 2nd ed.Oxford: Oxford University Press.

Dorson, Richard, ed. 1972. Folklore and Folklife: An Introduction. Chicago: University of Chicago Press.

Dunaway, David K., and Willa K. Baum, eds. 1996. Oral History: An Interdisciplinary Anthology. Lanham: AltaMira Press.

Eakin, Paul John. 1985. Fictions in Autobiography: Studies in the Art of Self-Invention. Princeton: Princeton University Press.

East Midlands. 2018. East Midlands Oral History Archive. In What is Oral History? Leicester: Center for Oral History, University of Leicester.

Esdaile, Charles. 2008. Napoleon's Wars: An International History. New York: Viking.

Fuchs, Rachel Ginnis. 2005. Gender and Poverty in Nineteenth Century Europe. Cambridge: Cambridge University Press.

Garrison, Tim Alan. 2004. “Cherokee Removal”. New Georgia Encyclopedia. Available online: https:/www. georgiaencyclopedia.org/articles/history-archaeology/Cherokee-removal (accessed on 1 July 2018). 
Gigantino, Jim. 2006. “Land Lottery System.” New Georgia Encyclopedia. Available online: https://www. georgiaencyclopedia.org/articles/history-archaeology/land-lottery-system (accessed on 15 July 2018).

Gordon, Milton M. 1964. Assimilation in American Life: The Role of Race, Religion, and National Origins. New York: Oxford University Press.

Greenblatt, Stephen. 1980. Renaissance Self-Fashioning: From More to Shakespeare. Chicago: University of Chicago Press.

Harré, Ron, and Fathali Moghaddam, eds. 2003. The Self and Others: Positioning Individuals and Groups in Personal, Political, and Cultural Contexts. London and Westport: Praeger.

Hubley, Martin. 2009. Desertion, Identity, and the Experience of Authority in the North American Squadron of the British Navy, 1745-1812. Ph.D. dissertation, The University of Ottowa, Ottawa, ON, Canada.

Hyde, Lewis. 2010. Trickster Makes This World: Mischief, Myth, and Art. New York: Farrar, Straus, and Giroux.

Jacobus, Donald Lines. 1999. Genealogy as Pastime and Profession, 2nd ed.Baltimore: Genealogical Publishing Company.

Johnson, J.M. 2003. Personal Interview, George West, TX, USA.

Johnson, Bernice. 2014. Personal Interview by E-mail communication, Menifee, CA, USA.

Kalaga, Wojciech, and Marzina Kubisz, eds. 2008. Multicultural Dilemmas: Identity, Difference, Otherness. Pieterlen and Bern: Peter Lang.

Keats-Rohan, Katherine S. B., ed. 2007. Prosopography: Applications and Approaches: A Handbook. Oxford: Prosopographica et Genealogica.

Kukla, Jon. 2003. A Wilderness So Immense: The Louisiana Purchase and the Destiny of America. New York: Alfred A. Knopf.

Lee, Jennifer, and Frank D. Bean. 2004. America's Changing Color Lines: Race/Ethnicity, Immigration, and Multiracial Identification. Annual Review of Sociology 30: 221-42. [CrossRef]

Lester, Clara. 1982. Telephone Interview, East Point, GA, USA.

Luckett, Matthew S. 2014. Honor Among Thieves: Horse Stealing, State-Building, and Culture in Lincoln County, Nebraska, 1860-1890. Ph.D. dissertation, University of California, Los Angeles.

Magra, Christopher P. 2016. Poseidon's Curse: British Naval Impressment and the Atlantic Origins of the American Revolution. Cambridge: Cambridge University Press.

O'Connor, Freddy. 1994. Liverpool: Our City, Our Heritage. Liverpool: Bluecoat Press.

O'Daniel, Patrick. 2007. The Primary Source: Issues in the Usability of Genealogical Records. Master's dissertation, The University of Tennessee, Knoxville, TN, USA.

Portes, Alejandro, and Min Zhou. 1993. The New Second Generation: Segmented Assimilation and Its Variants. The Annals of the American Academy of Political and Social Science 530: 74-96. [CrossRef]

Portes, Alejandro, Patricia Fernández-Kelly, and William Haller. 2005. Segmented assimilation on the ground: The new second generation in early adulthood. Ethnic and Racial Studies 28: 1000-40. [CrossRef]

Ragsdale, Blanche. 1995. Personal Interview, Pine Mountain, GA, USA.

Raynor, Caroline. 2011. 57-67 Dale Street, Liverpool, Merseyside: Archaeological Fabric Survey. Liverpool: Falconer Chester Hall Architects and Hawthorne Consulting.

Richardson, David, Anthony Tibbles, and Suzanne Schwarz. 2007. Liverpool and Transatlantic Slavery. Liverpool: Liverpool University Press.

Shotter, J., and K. J. Gergen. 1989. Inquiries in Social Construction Series, Vol. 2. Texts of Identity. Thousand Oaks: Sage Publications, Inc.

Stone, Lawrence. 1971. Prosopography. Daedalus 100: 46-71.

Szucs, Loretto Davis, and Sandra Hargreaves Luebking, eds. 2006. The Source: A Guidebook to American Genealogy, 3rd ed.Provo: Ancestry.

Toomeos-Orglaan, Karri. 2013. About Fairy Tale Genre on the Example of the Irish Narrative Tradition. Folklore 54: 171-74.

Waters, Mary. 1990. Ethnic Options: Choosing Identities in America. Berkeley: University of California Press.

Williams, Arden. 2007. “Textile Industry." New Georgia Encyclopedia. Available online: https://www. georgiaencyclopedia.org/articles/business-economy/textile-industry (accessed on 7 October 2018). 
Willigan, J. Dennis, and Katherine A. Lynch. 1982. Sources and Methods of Historical Demography. New York: Academic Press.

Wrigley, E. A., R. S. Davies, R. S. Scholfield, and J. E. Oeppen. 1997. English Population History from Family Reconstitution, 1580-1837. Cambridge: Cambridge University Press. 